\title{
Comparative Literary History in Assamese: Some Possibilities
}

\author{
Dhurjjati Sarma $^{+}$
}

\section{Abstract}

The essay attempts to explore some possibilities of Comparative Literary History with respect to Assamese literature. Writing a literary history is a complex business, and the tenets underlying its conceptualisation and execution have often been determined by factors other than purely 'literary' ones. In the essay, the conceptual dimensions of literary historiography are examined in relation to its recently developed nexus with comparative literature and cultural studies. Within this theoretical framework, the essay briefly touches upon the development of literary historiography within the Indian context in the precolonial, colonial and postcolonial periods, and subsequently moves on to discuss its position vis-a-vis Assamese literature, particularly in the latter's institutionalisation as a subject for graduate and postgraduate study under Gauhati University, Assam, in the post-Independence period. The essay deals specifically with the efforts of Professor Satyendranath Sarma, prominent academician and literary historian of Assam, towards the academic study of Assamese literary history. It explores the possibilities of comparative literary history in Assamese-one that is not based on a linear narrative of succeeding generations of poets and writers recorded and documented under a progressive model of impact and response, but rather a history of literary reception with many complex and multidimensional narratives often at loggerheads with each other.

Key words: Literary Historiography, Comparative Literature, Comparative Cultural Studies, Indian Literature, Assamese Literature, Satyendranath Sarma

\footnotetext{
${ }^{\dagger}$ Assistant Professor of Comparative Indian Literature, Department of Modern Indian Languages and Literary Studies, Gauhati University, Assam, Email: dhurjjati.sarma@gmail.com

(C) 2017 Sarma. This is an Open Access article distributed under the terms of the Creative Commons Attribution License (http://creativecommons.org/licenses/by/2.0), which permits unrestricted use, distribution, and reproduction in any medium, provided the original work is properly cited.
} 


\section{Introduction}

Why do we read or write literary histories? ... Literature [is often] regarded as a product and expression of a historical moment, a culture, and, above all, of a nation's spirit.... [And] historicity involves a continuous conflict and negotiation between past and present, contemporary and historical perspectives.

Literary texts do not merely reflect particular historical and cultural moments; more importantly, they constitute history through reading and rereading, they shape the personal and collective mentality of readers who participate in the social construction of reality (Marcel Cornis-Pope and John Neubauer, 2004: 1)

This article attempts to examine some of the possibilities of comparative literary history with respect to Assamese literature. It is well known that the act of writing a literary history is an endeavour to explore and document the nature and types of literary creations carried out within a group or community. Even though such an activity existed in various formats since the Middle Ages and even before, a concerted effort towards its formulation as a discipline was undertaken as part of the intellectual temper nurtured by Enlightenment ${ }^{1}$ in eighteenth-century Europe. That was a time, which fostered a belief in literary tradition as a marker of a community's shared social and cultural identity. The growth of nation-states as a political phenomenon further necessitated the record and documentation of people's past through tangible and intangible heritagemarkers. The subject of nationhood found a suitable ally in the discipline of literary history

\footnotetext{
1 “A movement in Europe from about 1650 until 1800 that advocated the use of reason and individualism instead of tradition and established doctrine" (Enlightenment, retrieved from, https://www.vocabulary.com/dictionary/Enlightenment). Here, the reference to the Enlightenment is made with reference to the area of literary study as it developed in Europe.
}

which, according to David Perkins (1992: 1), included "works on the literature of nations, periods, traditions, schools, regions, social classes, political movements, ethnic groups, women, and gays, and these studies foreground the genesis or production of texts, their effect on society or on subsequent literature, their reception, or all these moments synthetically".

However, the subject of literary history has not been without its share of criticism, as evident from various critics, including Rene Wellek, Robert E. Spiller and even David Perkins, who have raised questions regarding the credibility of the discipline's avowed endeavour to record and faithfully represent the events of the past. The past cannot be visualised as a thing-initself', complete in all aspects; it is in fact an 'event' that is constantly in flux, continually accruing to itself new meanings and dimensions. The past is characterised through the visions of the present. To quote from (1992; quoted from Singh, 2011: 5): “Contemporary studies can talk about past events with an awareness of misogyny, homophobia, racism, and colonialism that was unavailable to the people who experienced them, events that must have felt quite different from our imaginings." Therefore, in this condition, we may argue that what is present in literary history is not the 'representation' of the past, but its 'reconstruction' based upon the presentday imagination of the literary historian.

Further, there is question regarding the conceptual nature of literary history. What, exactly, is the function of literary history? Is it a mere chronological documentation of various literary works classified and presented in terms of period, genre or any ideological movement? Or rather what makes a particular history 'literary', and not 'political' or 'social'? David Perkins, in the chapter 'The Functions of Literary History' from his book Is Literary History Possible? sought to address this question in the following manner:

Literary history differs from history because the works it considers are felt to have a value quite different 
from and often far transcending their significance as a part of history. In other words, literary history is also literary criticism. Its aim is not merely to reconstruct and understand the past, for it has a further end, which is to illuminate literary works. It seeks to explain how and why a work acquired its form and themes and thus, to help readers orient themselves. It subserves the appreciation of literature. The function of literary history lies partly in its impact on reading. We write literary history because we want to explain, understand, and enjoy literary works. (Perkins, 1992: 177-8)

By aligning literary history with literary criticism, Perkins has emphasized upon the ontological function of the former alongside its usual genealogical obligations. Over and above chronological documentation, a literary history should enable the readers to understand the politics of representation vis-à-vis the reception and sustenance of a literary work both during and subsequent to the period of its composition. In addition, any literary work finds place in literary history not merely through authorial authority, but more importantly through its reception within the sensibility of the readers. Shakespeare, Milton, Wordsworth, and Dickens find mention in every possible book on the history of English literature because their works have found acceptance among the reading community across time and space and have exerted perceptible influence upon other works of literature composed in the subsequent periods of literary history.

In the Indian context too, there has been a long and sustainable tradition of literary criticism in Sanskrit and the regional languages that developed out of it, including Assamese. Therefore, with respect to the critical tradition prevalent in Sanskrit or in any of the bhasas (regional literature), there has been a perceptible and continued practice of defining what constitutes kavya (poetry and, by extension, literature) and consequently, delimiting the scope of works to be considered as sahitya (or literature) within the history of literature

Therefore, within the theoretical context mentioned above, the present article seeks to examine the possibility of understanding the literary history of Assamese from the perspectives of comparative literature and cultural studies. The following sections deal progressively with the development of literary historiography in India, particularly in the hands of colonial historians, while, at the same time, also looking at the way how literature and its textuality developed during the precolonial times, before moving on to talk about an Indian dimension to the hybrid discipline of comparative literary historiography. On the basis of the arguments and premises generated and discussed in the said sections, I would discuss (or rather explore) the possibilities for comparative literary history in Assamese.

\section{Literary Historiography in India}

The early days of literary history in the eighteenth and nineteenth centuries were motivated by nationalist and romantic aspirations. Literary history was, as already mentioned, closely associated with the project of national self-fashioning in Europe and subsequently permeated its colonies in Asia and Africa, including India under the British. In India, the early Orientalists undertook research and deliberated upon the subject of Indian literary history within the Enlightenment model borrowed from the West. However, prior to such studies, the medieval hagiographies or literature within the carita tradition could actually be considered as belonging to the genre of literary history of precolonial India. In Assam, there was a long tradition of buranjis (historical chronicles) composed under the patronage of the medieval Ahom court. However, I do not deny the possibility of historical writings in Assam before the advent of the Ahoms. Nevertheless, the Ahoms were the ones who started the tradition (or brought with them) of writing buranjis in Assam. Apart from that, charyapadas or the texts composed in Assamese during the Bhakti movement were 
not avowedly 'historical documents'; instead they were primarily 'socio-religious' texts that contained possible historical references, as all such texts do, to the contemporary events.

Notwithstanding, as noted by Blackburn and Dalmia (2004: 2), it was only in the nineteenth century that a modern literary and historical sensibility developed as part of the gradual transition from a mere recording of past events to rewriting it within the larger public debates surrounding the questions of national origins, linguistic identities and political entitlements. The nineteenth century witnessed new developments in the study of archaeology, epigraphy, anthropology, and folklore. Indian literary historiography also developed in consonance with the institutionalisation of these disciplines, which was directed towards conceptualising an understanding of Indian nationhood.

Early research into Indian literary history were undertaken by the European scholars motivated by an erroneous understanding that Indian literature was constituted majorly by what was composed within the cosmopolitan Sanskrit literary tradition, with the near exclusion of literature composed in the vernacular literary traditions of India. However, the closing years of the nineteenth century and early twentieth century witnessed the gradual consolidation of a veritable literary culture in many regional languages of India, including that in Assamese. It was also a period that heralded the nationalist phase of Indian history whereby aspects of colonial modernity, nationality and regional identities were merged and synthesised. Examples may be drawn from the works of Lakshminath Bezbaroa (Assamese), Bharatendu Harishchandra (Hindi) and Bankim Chandra Chatterjee (Bengali) who sought to synthesise elements of colonial modernity with a growing sense of national identity, accentuated by the awareness of being under the foreign rule, as well as a deep commitment to the cause of the regional culture into which they were born and of whose intricate features and characteristics they were inheritors.
At this point, if we may pause to reflect upon the basic objectives of colonial and nationalist literary histories of India, we would realise that attention was primarily based on the textcentric or printed canons of literature. Whether it was the case of Vedic or Sanskrit literary tradition, or the medieval hagiographical tradition, or even the new experimentations carried out under the impact of Western modernity, we witness the preponderance of written literature that defined and determined the features of Indian literary historiography. To quote Sheldon Pollock (2006: 4):

The invention of literacy and the growth of manuscript culture occurred in India a little before the beginning of the Common Era; from that point on, writing, the symbolic elevation of what is written, and the internal transformations the literary text undergoes by the very fact of being written down would become increasingly prominent features of literary culture.... In addition, writing makes possible the production of a history of a sort the oral is incapable of producing. These and other features mark the written as a distinct mode of cultural production and communication.

Literary histories of most Indian languages have, according to Pollock, prioritised the written word over the oral and performative dimensions, and, as such, marked the progress of a language from antiquity to modernity as a gradual transition from oral to written modes of literary transmission. Sheldon Pollock, in a series of books and articles, has sought to reassess the literary situation in South Asia, especially India, and, in the process, endeavoured to encompass the oral, printed (or written) and performative aspects within the ambit of literary tradition.

Under the 'Literary Cultures in History' project, Pollock and his collaborators attempted to understand what the texts of South Asian literature meant to the people who wrote, heard, saw, or read them, and how these 
meanings have changed over time. The attempt was to know what literary culture meant in history. "Instead of segregating the oral from the literate, or mechanically assuming that the transition to print was exported from Europe with the same consequences everywhere," the group, according to Pollock (2003: 15), "wanted to explore what relationships have existed between literature and the often simultaneous orders of oral, manuscript, and print cultures." They wanted to understand how the South Asians themselves conceived of their literary pasts and how they established their canons and conventions of literary judgement. The objective was to write not literary criticism but rather a history of what has been considered as the criticism of literature in the literary cultures of South Asia. In case of languages, these scholars aimed to show them not as "pure, selfidentical, thing like isolates" (a thing that most literary histories endeavour to do), but instead as "mutually constitutive processes" (Pollock, 2003: 15).

\section{Comparative Literary Historiography and the Indian Dimension}

With respect to the shift from a study of literary history towards the history of literary cultures, we can strongly emphasise upon the relevance of comparative literature, particularly, in the Indian context. Further, under the workmanship of Steven Totosy de Zepetnek since the 1980s, the gradual development of the discipline of comparative cultural studies marks the merger and extension of the tenets of comparative literature with those of cultural studies. In comparative cultural studies, emphasis is on the study of culture in relation to other significant forms of human expression as well as other disciplines in the humanities and social sciences. To quote Totosy (2003: 261): "While this direction does not give priority to the study of literature over other cultural fields, it does situate comparative literature in 'a global, inclusive, and multidisciplinary framework and an inter- and supranational' understanding of the humanities." In the recent years, the understanding inherent in the conceptualization of comparative cultural studies has been extended to the domain of literary history. In an essay entitled Rethinking Literary History-Comparatively, Mario Valdes and Linda Hutcheon (2002: 2) adequately summed up the basic objective of comparative literary history:

This broadening of the object of study not only increases the number of types of texts to be examined by literary historians, but also expands the historical contexts in which such texts will, of necessity, be considered.... Literary historians over the centuries have always been aware of the complexity of literary production, but the new methodological paradigms developed by various critical theories in the last few decades have made it impossible not to add to this an awareness of the equally complicated and equally significant nature of literary reception. What has come to be called the "literary institution"-the field in which literary experience occurs-is therefore as much a part of this history as is the development of genres or thematic motifs. For this reason, economic, political, and broader cultural and social perspectives on issues like race or gender must be brought to bear in the constructing of any "literary" history today.

Valdes and Hutcheon stated the above in the context of a proposed set of multi-authored volumes of comparative literary history to be published in a series sponsored by the International Comparative Literature Association (ICLA). To name a few, these volumes included Comparative Literary History of Latin America (Editor: Djelal Kadir), Comparative Literary History of the African Diaspora (Editors: Biodun Jeyifo and Henry Louis Gates, Jr.) and Comparative Literary History of Eastern and Central Europe (Editor: Wlad Godzich). A look into the titles of these literary history projects would suggest a 
gradual shift from the more traditional 'national' model of literary history to a 'comparative' one. This indicates an endeavour to move between past and present rather than presenting a linear narrative, and travel beyond the study of mere aesthetic and formal aspects of literature thereby taking into account important political, historical, geographical, sociological, anthropological and economic factors that impinge upon the production of literature within a community.

On the basis of these observations, we can think about the further possibilities of rethinking the literary history of the Indian languages. Sisir Kumar Das begins his prologue to A History of Indian Literature, 1800-1910 (1991: 1) with this statement: 'It is not possible to write a literary history of India without a framework that accommodates not only the diverse literary traditions existing in the country but also the complexities of its multilingualism.' Therefore, for a reassessment of the situation of literary history in India, it is important to explore and uncover the various dimensions of interactions and interpenetrations among the regional language literature.

\section{Exploring Possibilities for Comparative Literary History in Assamese}

As indicated in the title, the present essay will examine the premises that have been considered while conceptualising the idea of Assamese literary history in the twentieth century. As mentioned earlier, there was a long and rich medieval tradition of history-writing in Assamese in the form of prose chronicles called buranjis and which offered a narrative and chronological documentation of multiple aspects concerning Assam, including its history, geography, religion, literature and society. Since the beginning of the twentieth century, Assamese intellectuals like Debendranath Bezbaroa, Hemchandra Goswami, Banikanta Kakati, Suryya Kumar Bhuyan, and Dimbeswar Neog had been engaged in the task of collecting old manuscripts from various sources and thereby conceptualising a history of Assamese literature. Following Independence in 1947 and the establishment of Sahitya Akademi in 1954 under the motto of "Indian Literature is one though written in many languages," the project of formulating individual literary histories of Indian languages recognised by the Sahitya Akademi was undertaken during the 1960s and 1970s. Birinchi Kumar Barua was entrusted with the responsibility of composing the History of Assamese Literature (1964). In addition, with the establishment of the Gauhati University in 1948 and the subsequent introduction of graduate and postgraduate courses in Assamese necessitated the composition of histories of Assamese literature.

One of those many significant personalities whose lifelong endeavour shaped the presentday discipline of Assamese literature was Professor Satyendranath Sarma. In the course of our discussion in the preceding paragraphs of this essay, we have witnessed the importance of literary history as a subject of study and the significance of the role envisioned for comparative literature (and by extension, comparative cultural studies) vis-avis the study of literary history. Moreover, as an academician, Professor Sarma was actively engaged in the process of composing histories of Assamese literature. He wrote a comprehensive history of Assamese literature entitled Asomiya Sahityar Samikshatmak Itibritta. An initial version of this work had appeared as Asomiya Sahityar Itibritta in the year 1959. The work ran through seven editions before the aforementioned updated version was published in 1981 whereby works composed from the onset of literary activity in Assamese until 1980. In addition to this work, Professor Sarma has to his credit four more books on the history of Assamese literature. They are, namely, Asomiya Natya Sahitya (1962; A book documenting the history of drama in Assamese literature), Asomiya Upanyashar Bhumika (1965; An Introduction to Assamese Novel), Asomiya Kahini Kavyar Prabah (1970; Trends in Assamese Poetic Fiction) and Asomiya Upanyashar Gatidhara (1976; Trends in the Development in Assamese Novel). 
Through these books and a few others, Professor Sarma made consistent attempts to document and record the development of various genres and forms within Assamese literary tradition from the beginning until around the 1980s.

An immediate concern accompanying any study of literary study, particularly in the Indian context, is the issue of periodisation. Studies on Indian history and regional histories, literary or otherwise, have mostly adhered to the imported tripartite model of Ancient/Medieval/Modern. According to William A Green (1995: 99-111):

[T] ]he ancient/medieval/modern formula currently in use had its origins in Italian humanist thinking, but acceptance of this tripartite model did not become universal until the nineteenth century. Since then, tripartite periodization has gripped Western academe like a straitjacket, determining how we organize departments of history, train graduate students, form professional societies, and publish many of our best professional journals.

Inspired by this model via the colonial influence, Indian historians have stuck more or less to this model, and literary historians too have attempted to classify their studies in terms of ancient, medieval and modern periods of Indian literature. If we consider Professor Sarma's Asomiya Sahityar Samikshatmak Itibritta, which is often referred to as an authoritative account of Assamese literary history, we find the following pattern of periodization:

1. Ancient Period: Literature from the beginning of literary creation, 9501300 CE, Charyapadas, Mantra Literature

2. Medieval Period: a) First Phase: Literature from the Pre-Sankardeva Era, 1300-1490 CE b) Second Phase: Literature from the Sankardeva Era, 1491-1700 CE

c) Third Phase: Literature from the Post-Sankardeva Era, 1700-1830 CE

3. Modern Period: a) First Phase: Age of Missionary Literature, 1826 (36)-1870 CE

b) Second Phase: Age of Hemchandra and Gunabhiram, 1870-1890 CE

c) Third Phase: Romantic Age or Age of Bezbaroa, 1891-1940 CE

d) Fourth Phase: Contemporary Period, 1940 CE onwards.

Source: Asomiya Sahityar Samikshatmak Itibritta, p. 11.

Interestingly, Professor Sarma has only outlined the possibility of periodising Assamese literary history in the manner cited above. In the book, he divides the subject matter into seventeen chapters. In the introductory chapter, he marks the beginning of the Assamese literary tradition with the composition of the Charyapadas ( $p$. 10). Composed by the Tantric Buddhist Siddhacharyas in Assam-Kamarupa at various periods between the ninth and the twelfth century, the Charyapadas are recognised as poems of a high mystic nature and, most importantly, considered the first written specimen of the proto-Assamese literature. However, Sarma here is adhering to the conventional elevation of what is written down over the oral and performative forms, as claimed as Pollock, as the distinct feature of a literary culture. Contemporaneous with Charyapadasand in the later periods were the miscellaneous specimens of oral literature in the form of folksongs, traditional idioms and folktales. Being oral and subject to mutations and modifications over time, it is difficult to ascertain the exact dates of their composition and nature of circulation. However, as 
components of the Assamese literary culture, they deserve to be looked at more critically as markers of a developing Assamese sensibility at the turn of the first millennium.

Coming to the medieval period, we can see that the literary activities included therein have been categorised around the corpus of literature mainly composed by Sankardeva and his associates from the closing years of the fifteenth century to around $1700 \mathrm{CE}$. However, as belonging to pre-Sankardeva era, literary compositions in Assam that were primarily based on the epics Ramayana and Mahabharata date back to the fourteenth century with the Madhava Kandali's translation of Valmiki's epic into Assamese. Other poets, namely, Hem Saraswati (Prahlada Carit), Harivara Vipra (Ashwamedha Parva, Babruvahanar Juddha, Lava-Kushar Juddha, Tamradhwajjar Juddha), Kaviratna Saraswati (Jayadratha Vadha) and Rudra Kandali (Drona Parva, Satyaki Prabesh) of the pre-Sankardeva period composed episodic kavyas in Assamese, which were based on the stories from the Ramayana and Mahabharata. All these texts are seen as precursors to the radical formulisation of the Assamese Vaishnava literary culture by Sankardeva through ekasarana namdharma. In Asomiya Kahini Kavyar Prabah (1970), Professor Sarma has provided in-depth analyses of the aforementioned kavyas under various categories, namely, short poetic fictions (laghukavya), heroic poems (bir-kavya), didactic or revelatory poems (mahatmya kavya), conjugal poems (parinaya- or pranay-kavya), modern kavyas, historical kavyas and other miscellaneous poetic fictions. In most literary histories, these kavyas, barring the modern and historical ones, are generally considered as laying the ground for the subsequent flowering of Vaishnavite literary culture. Even Professor Sarma has acknowledged the precursory roleplayed by the aforementioned poets, most importantly, Madhava Kandali vis-a-vis the literary production of the Sankardeva era. However, by adopting this approach, we are running the risk of overlooking certain other aspects, which are highly relevant towards developing an independent understanding of the characteristic features of the preSankardeva era, not necessarily contributing to a latter-day Vaishnavite literary movement.

Further, the assimilation of the distinguishing features of an age under the appellation of one person or one religious ideology effectively marginalises all other existent, not necessarily competing or dissenting, traditions thereby straitjacketing all of them into a linear and hegemonic narrative. In addition, the danger inherent in the act of pulling together all literary practitioners under an umbrella designation is that we create homogeneous narratives around the literary epoch. With respect to the English Romantic Movement as an 'event' within English literary history, David Perkins (1992: 87-88) says:

In England between 1798 and 1824, the term romantic did not designate a contemporary literary movement or period. The adjective was widely current, and meant wonderful, exotic, like a medieval romance. After 1813, the influential distinction of the Schlegel brothers between classical literature or culture and the romantic or modern was known to English critics, but in this distinction romantic or modern referred to the literature of the late Middle Ages and Renaissance. The poets we now group together [as Romantics] seemed very different. Overall, they disliked each other at least as much as they were friendly and admiring. To the poets and their contemporaries, their relative standing at present would have seemed time's incomprehensible caprice. The canon of contemporary poets in 1820 generally began with Byron, Scott, Campbell, Wordsworth, and Moore. Blake was unknown; Shelley and Keats had few readers; the genius of Coleridge as a poet was not widely recognised.

In the case of Assamese literary histories, including the authoritative ones composed by 
Professor Satyendranath Sarma and Professor Maheswar Neog, the existence of period markers like Sankari Yug or Vaishnav Yug may thus seem a retrospective construction of a glorious period in the history of Assamese literature in terms of the representative features of the dominant ideology (Vaishnavism) of the time and thereby fall short of directing our understanding towards the diverse literary-cultural formations of the stated period. At this point, we may reiterate the efficacy the comparative cultural studies towards enabling an inclusive and multidisciplinary framework and understanding of literary activities undertaken not only during the medieval period of Assamese history, but also in the subsequent periods of its literary history. For instance, the incomprehensible caprice' mentioned by Perkins above may also be extended to our theorisation of the modern period of Assamese literature as clusters of supposedly likeminded literary activities undertaken under the aegis of missionary service or the Jonaki circle of intellectuals. By equating the Romantic Age roughly with the time span of Lakshminath Bezbaroa's literary career, as done within the periodisation model by Professor Sarma, can we realistically visualise the nature of literary activities of the period as part of the collective production of literary pleasure and interest. To quote Stephen Greenblatt (1988: 4):

[The] production of literary pleasure and interest ... is collective since language itself, which is at the heart of literary power, is the supreme instance of a collective creation. But this knowledge has for the most part remained inert, either cordoned off in prefatory acknowledgments or diffused in textual analyses that convey almost nothing of the social dimension of literature's power. Instead the work seems to stand only for the skill and effort of the individual artist, as if whole cultures possessed their shared emotions, stories, and dreams only because a professional caste invented them and parceled them out.

This brings us to the complicated yet equally significant aspect of literary reception. In any discussion of an author's place within the literary traditions, we ought not only to understand the extent to which he/she was successful in utilising the linguistic and cultural resources made available to him/her by the contemporary social and cultural milieu, but also record and document the ideologies and frameworks within which that particular author gets projected in the subsequent periods of the literary tradition. Bezbaroa's projection of Sankardeva as the 'cultural hero' of Assamese nationalism in the early twentieth century is a case in point. With respect to William Shakespeare's continued popularity within the English literary tradition, Jonathan Bate (1989: 1) once remarked, "'Shakespeare' is not a man who lived from 1564 to 1616 but a body of work that is refashioned by each subsequent age in the image of itself." In a similar vein, K.N. Phukan (1996: 142) says: “Bezbaroa's rediscovery of Sankaradeva was inspired partly by the wish to affirm by celebration the joy of faith and partly in order to identify in neoVaishnavism a foundation of the expansive and importunate ethos of the Assamese as a distinct nationality in the combined terms of a common faith, culture, language and a vaguely defined and standoffish political temper."

Therefore, Bezbaroa's reception of Sankardeva and the entire accompanying Vaishnavite ethos need to be reanalysed within the context of Assamese modernism. Similarly, the presentday response to Bezbaroa and the recent observance of his $150^{\text {th }}$ birth anniversary deserve similar attention with respect to his elevation as the 'maker of modern Assamese literature' or the 'harbinger of Assamese modernism'. We ought to understand that such epithets are part of the retrospective 'imaging' of a great personality from the past whose credentials are subsequently reconstructed visa-vis the exigencies of the present time. All these 'reimagining' and 'reconstruction' processes are part of a community's 'literary 
experience'. The modern Assamese society would have known about Sankardeva even without the agency of Bezbaroa. But what Bezbaroa has done is to reorient and establish the Assamese perception of Sankardeva within a specific ideology. Going back to the medieval age, we can argue similarly about Sankardeva's own repositioning of Madhava Kandali's Ramayana to fulfil the objectives of the NeoVaishnavite Movement. Could there have been an alternative prospect of knowing Madhava Kandali, not as a pre-Sankardeva or preVaishnavite poet who unknowingly/posthumously contributed to an epoch-changing movement that happened many years and decades after his death, but as a poet translating the Ramayana under the patronage of a tribal king and thereby catering to the untutored and un-proselytised sensibility of a community. This is what Manjeet Baruah (2012: 68) said with respect to Madhava Kandali's $14^{\text {th }}$ century Sat Kanda Ramayana and the Sankari intervention in the text: "Two notable features about Kandali's text are that it was aimed at/for royal clientele, i.e., 'tribal' monarchy, and that the text has a social base which is 'tribal-peasant' in nature.... The 'reflection' of the social base in the text can be found, for example, in the nature of access that common people were shown to have to the royal palace as well as in the nature of gender relations that mediated social relations."

\section{Implications}

By studying the aforementioned dimensions impinging upon the reception and reconstruction of a literary text within the tradition of its circulation, we are moving closer to the tenets of comparative literary history. Therefore, not only literary, but also broader perspectives centring on culture and society must be brought to contribute to the presentday study of literary history. Assamese literary tradition, or any literary tradition for that matter, is not a linear narrative of succeeding generations of poets and writers recorded and documented under a progressive model of impact and response. History of literary reception is one with many complex and multidimensional narratives often at loggerheads with each other. The job of the literary historian is not to iron out those conflicts and inconsistencies for the sake of providing a plausible narrative of literary events. Hindsight is a positive attribute but it must not lead to overt rationalisation of otherwise contingent and tentative incidents that might have occurred in the annals of literary history.

\section{References}

Barua, Birinchi Kumar. 1964. History of Assamese Literature. Delhi: Sahitya Akademi.

Baruah, Manjeet. 2012. Frontier Cultures: A Social History of Assamese Literature. New Delhi: Routledge India.

Bate, Jonathan. 1989. Shakespearean Constitutions: Politics, Theatre, Criticism, 1730-1830. Oxford: Clarendon Press.

Blackburn, Stuart and Vasudha Dalmia (ed.). 2004. India's Literary History: Essays on the Nineteenth Century, New Delhi: Permanent Black.

Cornis-Pope, Marcel and John Neubauer (eds). 2004. "General Introduction." In History of the Literary Cultures of East-Central Europe: Junctures and Disjunctures in the 19th and $20^{\text {th }}$ Centuries. Amsterdam: John Benjamins.

Das, Sisir Kumar. 1991. A History of Indian Literature, 1800-1910. Delhi: Sahitya Akademi.

Green, William A. "Periodizing World History", History and Theory, Vol. 34, No. 2, (May, 1995), pp. 99-111.

Greenblatt, Stephen. 1988. Shakespearean Negotiations: The Circulation of Social Energy in Renaissance England. Berkeley and Los Angeles: University of California Press.

Perkins, David. 1992. Is Literary History Possible?. Baltimore, London: Johns Hopkins University Press. 
Phukan, K.N. 1996. 'Bezbaroa's Analytical Perspectives in Sankaradeva Studies'. In Ranjit Kumar Dev Goswami (ed.), Essays on Sankaradeva, Appendix-A. Guwahati: Forum for Sankaradeva Studies and Lawyer's Book Stall, pp.138-160.

Pollock, Sheldon. 2006. The Language of the Gods in the World of Men: Sanskrit, Culture, and Power in Premodern India. California: University of California Press.

Pollock, Sheldon., ed.2003. Literary Cultures in History: Reconstruction from South Asia. California: University of California Press.

Sarma, Satyendranath. 1962. Asomiya Natya Sahitya. Guwahati: Soumar Prakash

Sarma, Satyendranath. 1965. Asomiya Upanyashar Bhumika. Guwahati: Soumar Prakash.

Sarma, Satyendranath. 1970. Asomiya Kahini Kavyar Prabah. Guwahati: Bani Prakash.
Sarma, Satyendranath. 1976. Asomiya Upanyashar Gatidhara. Guwahati: Soumar Prakash.

Sarma, Satyendranath. 1981. Asomiya Sahityar Samikshatmak Itibritta. Guwahati: Soumar Prakash.

Singh, Ahanthem Homen. 2011. 'Historiography of Literature for Literatures with a Short Literary History', Unpublished MPhil Dissertation. Submitted to the Department of Modern Indian Languages and Literary Studies, University Of Delhi.

Totosy De Zepetnek, Steven. (ed.). 2003. Comparative Literature and Comparative Cultural Studies. Indiana: Purdue University Press.

Valdes, Mario and Linda Hutcheon. Rethinking Literary History- Comparatively, ACLS Occasional Paper, No. 27. 